\title{
Empathy, the song and the singer: a legacy of Robert Schumann
}

\section{John Cox}

\begin{abstract}
SUMMARY
In this article it is suggested that empathy is a core component of musical appreciation and particularly of the relationship between the singer and the audience. The brain pathways activated in musical appreciation are outlined and the nature of the empathic process considered with reference to Robert Schumann's songs and his experience of severe mental disorder. The article suggests that listening to Schumann's song cycle Dichterliebe (Poet's Love), or to other great music, is a useful component of continuing professional development and that such experience enhances therapeutic effectiveness and empathy, as well as increasing the understanding of the relationship between creativity and mental health.
\end{abstract}

\section{DECLARATION OF INTEREST}

None.

In October 2010, the 200th celebrations of the birth of Robert Schumann (1810-1856) and a 'Musical Brain' conference in London brought together a rare combination of musicians, neuroscientists, psychiatrists and service users to consider the effect of mental disorder on artistic creativity with reference to Schumann's life-long health and personal problems. The English tenor James Gilchrist (a doctor who became a top-class professional singer) performed Schumann's song cycle Dichterliebe. This performance and the author's presentation on music and empathy each facilitated further exploration of these themes for continuing professional development.

\section{Empathy, the song and the singer}

Empathic communication between musician and audience is at the heart of much musical experience. The mezzo soprano Janet Baker (1983) described the art of the singer as striving to mirror to an audience the 'great works placed in our hands' and emphasised that the task of the singer was to make sure that the glass was polished brightly. Kathleen Ferrier was another gifted singer whose rich voice and transparent personality fully engaged an audience in the concert hall and facilitated her work with musicians such as Benjamin Britten and
Peter Pears. Such empathic capacity is also central to the effectiveness of most person-centred medical practice (Cox 2010).

Nevertheless, to understand how such mentalising and aesthetic 'judgement' about another's emotional life occurs during a musical performance is most complex and requires conceptual and scientific insights from musicology, neuroscience, psychology, philosophy and, for religious music, theology. This communicative process, for example, is facilitated by musical notation, auditory signals in the cochlea and eighth nerve, symbolic and iconic components (patriotic and religious songs) and meaningful engagement between the musician and the audience. Pre-conscious processes (transference and projective identification) that energise this affective exchange are useful psychoanalytic concepts to consider; they are of particular relevance to the work of music therapists, who specifically utilise musical expression as a mode of communication with clients (Aldridge 1996; Pavlicevic 1997). Furthermore, an understanding of the symbolic and ritualistic elements of music-making, and especially of opera (Storr 1992), is enhanced by considering the relevance of cultural history and of artistic archetypes. The sociodynamics of the large-group process and the nature of kinaesthetic empathy (Cox 1987) may also partially explain social and somatic responses to music. The audience in a large concert hall, for example, can experience a contagious wave of emotion and of physical sensations, such as 'chills' or 'shivers', in response to the gestures and synchronised movements of the orchestra and conductor - as well as to the rhythms, pitch and timbre of the music.

'Simulation theory' (Gordon 1992), which resembles Jaspers' concept of fellow feeling (Thornton 2009), is close to the popular assumption that the audience shares emotions with the performer, who in turn interprets the composer's intentions. The 'theory-theory' (Carruthers 1996) of empathy, whereby knowledge of another's mind is accessed only 'in theory' and is not a shared experience, lacks face validity with regard to musical experience.

How this empathic capacity is acquired, whether in infancy from pre-verbal intersubjective experience
John Cox is Professor Emeritus of Psychiatry at Keele University, UK, and had been President of the Royal College of Psychiatrists and Secretary General of the World Psychiatric Association. He studied singing part time at the Guildhall School of Music and Drama in London when a medical student and continues his interest in performing English songs, lieder and oratorios Correspondence Professor John Cox, Centre for the Study of Faith, Science and Values in Health Care Francis Close Hall, University of Gloucestershire, St Paul's Road, Cheltenham, GL50 4AZ, UK. Email: john1.cox@virgin.net 
with a caregiver (Trevarthen 1980) or from the effect of sung lullabies on brain development (Standley 2002), or later from musical training and the medical humanities, is still to be fully answered.

\section{Neuroscience}

The empathic response of the listener to music can be partially facilitated by the activation of mirror neurons (Gallese 2001) in both the left and right brain, which simulate observed actions and intents in others, as well as by activity of the complex



$\mathrm{FL}$, frontal lobe; HG, Heschl's gyrus (site of primary auditory cortex); INS, insula (shown with overlying cortex removed): LC limbic circuit (shown with overlying cortex removed): MTG, middle tempora gyrus; PL, parietal lobe; PT, planum temporale; STG, superior temporal gyrus; TP, temporal pole.



A scheme for the organisation of the musical brain based on evidence from the study of healthy and damaged brains. Key brain areas are shown above and major functional associations of these areas are represented below. Arrows indicate the predominant flow of information between cortical areas (most of these connections are bidirectional). Overall, there is a right hemisphere functional preponderance for processing a number of components of music. However, this selectivity is relative rather than absolute and a similar qualification applies to the processing of particular musical components by different brain areas within a hemisphere. Partly independent brain networks govern perceptual analysis and emotional response. The scheme indicates the broadly hierarchical nature of music processing, with more complex and abstract properties represented by areas further beyond primary auditory cortex. (From Warren 2008. (C) 2008 Royal College of Physicians. Reproduced with permission.) interconnected neuronal circuits (Koelsch 2004; Warren 2008). These circuits include auditory pathways, the amygdala, insula and the limbic system, as well as a hierarchical network of linked cortical areas. Figure 1 illustrates that the 'old idea' of musical appreciation being lateralised to specific brain areas is now replaced by music being regarded as a 'whole brain' phenomenon with an overlap to brain circuits necessary for speech.

Jason Warren (2008) concluded his review by suggesting that, although the 'how' of music is beginning to be understood, the greater challenge now is to answer the question of 'why' the brain processes music. It is likely that the answer to this question will require increased awareness of the contribution of the right brain to human consciousness and to emotional intelligence (McGilchrist 2009), as well as knowledge of evolutionary theory, ethology and comparative religion. The rhythms and melodic line of music, for example, which may reinforce speech as well as dance, may promote the group cohesion necessary for human survival and can dissipate strong emotions that threaten the group function.

The neuropsychiatrist Michael Trimble (2007) has considered these questions in his book The Soul in the Brain, which straddles the borders of neurology and music (particularly opera) and makes a cogent case for the specialty of neurotheology. Contemporary composers such as James MacMillan (2010) describe music as having a 'sacred essence which reaches into the soul and releases a divine force'. Karen Armstrong (2009) regards music as having meanings that do not translate into 'logical structures or verbal expression'. It is indeed this contextual framework, and especially the personalised 'I-Thou' quality of music, that gives it its particular power to transmit emotions.

\section{Training issues}

It is likely, therefore, that appreciation of music, as well as of poetry, visual arts and drama, can enhance the understanding of the person and also sensitise doctors to recognising their own emotional responses. Green (2009) has suggested in this journal that an empathic process establishes the emotional response of the onlooker to a painting and that there is a 'relationship' with its sentiment - and with the creativity of the artist. Oyebode (2009) made a similarly cogent case in this journal for the role of literature and narrative in medical education at all levels. Yet, curiously, the teaching of music appreciation to enhance such emotional sensitivity and empathy is only rarely included in humanities curricula. The musicologist Anthony Hopkins (1979) has explained this neglect by 
observing that music, unlike a poem or painting, is an art form that is constantly renewed and revitalised as it is performed, so cannot be put into a cupboard or taken home. There is nevertheless a common understanding that doctors often have musical interests. Orfi (2009) has described how her resumption of cello practice assisted clinical work and also enabled greater companionship with other doctors.

\section{Schumann and mental disorder}

Schumann died in 1856 in an asylum at Endenich near Bonn in Germany. He had been admitted 2 years earlier after an episode in which he had wandered in a thin robe and slippers towards the Rhine toll bridge (O'Shea 1990) and then suddenly thrown himself into the freezing water. He was rescued by a fisherman and admitted voluntarily to the asylum under the care of Dr Franz Richarz.

There was a strong family history of mental disorder. Schumann's sister Emilie had a schizophrenic-type illness and took her own life. His son Ludwig probably had a severe schizophreniform mental disorder and was hospitalised for 25 years. Domschke (2010) describes his father as 'a melancholic', and a cousin of the father died by suicide at the age of 41 . Schumann's personality was also unusual. He had obsessional characteristics, a preoccupation with his hands and an active fantasy world populated by two literary figures, Florestan and Eusebius, with contrasting personalities.

Speculation as to whether Schumann's final illness was neurosyphilis continues. Interestingly, Ostwald $(1985,1987)$ excluded this possibility in his DSM-IV diagnosis on the basis of the reported symptoms. Schumann's symptoms and family history, according to Domschke (2010), suggested that he had a schizoaffective disorder with a major genetic susceptibility conferred by overlapping genes. The title of her article even suggested that Schumann made a 'contribution to the understanding of the genetics of psychosis', although, in my opinion, his greater legacy was his creative gifts as a composer of lasting importance (Fig. 2).

Three of Schumann's song cycles (Liederkreis, Op. 24 and Op. 39, and Dichterliebe, Op. 48) were composed in 1840 , the year after his long-awaited marriage to Clara Wieck - the daughter of his piano teacher, who was adamantly opposed to the marriage. Clara was an exceptionally gifted pianist who also composed and was much admired by Brahms.

The poems by Heine (Op. 24, Op. 48) and Eichendorff ( $O p .39$ ) display the full range of human emotion, yet these sentiments are sometimes expressed sparingly in the songs - Anfangs wollt' ich fast verzagen (Op. 24) has only 11 bars. How frequently Schumann met up with Heine is unknown, but they were both lawyers and were familiar with Düsseldorf and so had much in common. They were both influenced by the postEnlightenment Romantic movement that was popular in Germany at the time.

When composing the music for the last song of the Dichterliebe song cycle, Die alten bösen Lieder (The Old Bad Songs), Schumann was reflecting on his extreme emotions of depression, anxiety and insomnia, as well as on his particular marital problems. An empathic listener can sense the effort of the 12 giants, who were required to carry a huge coffin full of thwarted love on planks even longer than the bridge at Mainz and then to bury it in the sea. In performance, the singer strives to convey these emotions, to understand the poet's and the composer's intentions and to communicate to the audience in a way that will engage their imagination and empathic process. Singer and accompanist require an accurate empathic understanding of each other and of their audience to reflect faithfully the composer's intentions. They also require a flawless technique and the imagination to interpret poetic metaphor and musical expression.

It is suggested by O'Shea (1990) that Schumann's medical treatment in the asylum was narrowly biological, despite the popularity at that time of the Romantic movement, which would have encouraged the contextual social and psychological understanding of the mental disorder. Clara only visited the asylum the day before Robert died.

In my experience, musicians do not always obtain optimal medical help - and it is likely that this was so for Schumann.

\section{Therapy for musicians}

Many psychiatrists and psychotherapists have had clinical experience treating patients who were musicians. It is therefore unfortunate that



Robert Schumann's hypothetical pedigree with respect to the segregation of menta disorders in his family (Domschke 2010). 
this tacit knowledge - the craft of medicine (Montgomery 2006) - is rarely documented. However, North \& Hargreaves (2008) have reviewed cognitive and behavioural techniques, as well as medication, for the treatment of performance anxiety. They also cite Wilson (2002), who listed three factors to be considered when applying a stress-performance model to musicians: trait anxiety of the performer; the degree of task mastery; and the degree of situational stress in performance. A fourth category of career stress and work overload also has to be considered.

The experience of therapists using psychodynamic models in the treatment of musicians is also rarely reported. Clinical accounts of the management of depressive or anxiety disorders of moderate severity affecting bodily coordination and breath control of the singer or wind player are likewise uncommon.

The stresses of a large group experienced by orchestral players include the fear of underperformance and of scrutiny by the conductor or section leader, which may lower self-esteem and precipitate depression in a vulnerable musician. Other stresses include the practical demands of international tours, absence from family members and the effects of excessive alcohol consumption. Professional singers are particularly dependent on their voice for their livelihood and may become fearful of developing a throat infection or laryngeal abnormality. Some international soloists are reported to have eccentric personalities and to use rituals to enhance their performance and facilitate prolonged practise.Yet composers and musicologists with bipolar disorder may regard cyclothymia as a spur to composition, although they generally recognise the adverse effect on performance of severe depression or elation, and also the risk of self-harm.

\section{Concluding reflection}

Finding an integrative scientific and humanistic paradigm to contain the musical ideas and concepts explored in this article is not straightforward. It is suggested, however, that a body-mind-spirit (i.e. meaning, purpose) paradigm may be helpful to encourage the scientific understanding of empathy and also of the process and content of musical performance. It is also suggested that listening to Dichterliebe (or to other great music) and 'going with' the composers and their narratives are valuable components of continuing professional development. Empathic understanding of patients and therapeutic skills can be enhanced and creativity and compassion in the workplace sustained.

\section{References}

Aldridge D (1996) Music Therapy Research and Practice in Medicine: From Out of the Silence. Jessica Kingsley Publishers.

Armstrong K (2009) The Case for God: What Religion Really Means. Bodley Head.

Baker J (1983) The life of a singer today. In Voice (ed Y Menuhin): 87-94. Macdonald.

Carruthers P, Smith PK (1996) Theories of Theories of Mind. Cambridge University Press.

Cox JL (2010) Empathy, identity and person-centred medicine. The sociocultural context. Journal of Evaluation in Clinical Practice 17: 350-3.

Cox M, Theilgaard A (1987) Mutative Metaphors in Psychotherapy: The Aeolian Mode. Tavistock Publications.

Domschke K (2010) Robert Schumann's contribution to the genetics of psychosis. Psychiatry in music. British Journal of Psychiatry 196: 325.

Gallese V (2001) The 'shared manifold 'hypothesis. From mirror neurones to empathy. Journal of Clinical Studies 8: 33-50.

Gordon RM (1992) The simulation theory: objections and misconceptions. Mind and Language 7: 11-34.

Green J (2009) Form and mental state: an interpersonal approach to painting. Advances in Psychiatric Treatment 15: 137-45.

Hopkins A (1979) Understanding Music. Dent \& Sons.

Koelsch S, Kasper E, Sammler D, et al (2004) Music, language and meaning. Brain signatures of semantic processing. Nature Neuroscience 7: 302-7.

MacMillan J (2010) Music and the Sacred. New College Choir Association Newsletter June. Choir of New College Oxford.

McGilchrist I (2009) The Master and his Emissary: The Divided Brain and the Making of the Western World. Yale University Press.

Montgomery K (2006) How Doctors Think: Clinical Judgement and the Practice of Medicine. Oxford University Press.

North A, Hargreaves D (2008) The Social and Applied Psychology of Music. Oxford University Press.

Orfi D (2009) The art of medicine: thoughts on a $\mathrm{G}$ string. Lancet 373: $116-7$.

0'Shea J (1990) Music and Medicine: Medical Profiles of Great Composers. Dent.

Ostwald PF (1985) Schumann: Music and Madness. Victor Gollantz.

Ostwald PF (1987) The Inner Voices of a Musical Genius. Northeastern University Press.

Oyebode $\mathrm{F}$ (2009) The humanities in postgraduate medical education. Advances in Psychiatric Treatment 15: 224-9.

Pavlicevic M (1997) Music Therapy in Context: Music, Meaning and Relationship. Jessica Kingsley Publishers.

Standley JM (2002) A meta-analysis of the efficacy of music therapy for premature infants. Journal of Pediatric Nursing 17: 107-13.

Storr A (1992) Music and the Mind. HarperCollins.

Thornton T, Fulford KWM, Christodoulou G (2009) Philosophical perspectives on health, illness and clinical judgement in psychiatry and medicine. In Psychiatric Diagnosis: Challenges and Prospects (eds IM Salloum, JE Mezzich): 15-27. John Wiley \& Sons.

Trevarthen CB (1980) The foundations of intersubjectivity. Development of interpersonal and cooperative understanding in infants. In The Social Foundations of Language and Thought: Essays in Honour of JS Bruner (ed DK OIson): 316-42. Norton.

Trimble MR (2007) The Soul in the Brain. Johns Hopkins University Press.

Warren J (2008) How does the brain process music? Clinical Medicine 8: $32-6$

Wilson GD (2002) Psychology for Performing Artists (2nd edn). Whurr. 